\title{
Determination of Antimicrobial Activity of Different Essential Oils Obtained from Plants on Staphylococcus aureus Strains Isolated from Foods
}

\author{
Hacer Aslan Canberi ${ }^{1, a}$, Esra Şentürk ${ }^{2, b}$, Simge Aktop $^{2, c}$, Pınar Şanlıbaba ${ }^{2, d, *}$ \\ ${ }^{1}$ Biotechnology Institute, Ankara University, $60^{\text {th }}$ Year Settlement, 06110 Dişkapı/Ankara, Turkey \\ ${ }^{2}$ Department of Food Engineering, Engineering Faculty, Ankara University, 50 ${ }^{\text {th }}$ Year Settlement, 06830, Gölbaşı/Ankara, Turkey \\ *Corresponding author
}

\begin{tabular}{l|l}
\hline A R T I C L E I N F O & A B S T R A C T \\
\hline Research Article & $\begin{array}{l}\text { Essential oils (EOs) are known for its antimicrobial activity against several pathogenic bacteria. The } \\
\text { present work evaluated the antimicrobial activity of } 15 \text { different EOs on survival of different strains } \\
\text { of different Staphyloccocus aureus strains isolated from traditional cheeses by disc diffusion method. } \\
\text { The most antimicrobial activity on the strains was found as oil thyme oil (mean zone diameter } 23.203 \\
\text { mm). Clove oil and black seed oil had the highest antimicrobial activity after thyme oil with average } \\
\text { zone diameters of } 13.698 \mathrm{~mm} \text { and } 11.267 \mathrm{~mm} \text { respectively. Hypericum perforatum } \mathrm{L} \text { oil (mean zone } \\
\text { Received : 08/02/2020 mm), ginger oil (mean zone } 6.250 \mathrm{~mm} \text { ) and garlic oil (mean zone } 6.267 \text { mm) were the lowest } \\
\text { accepted : 23/03/2020 } \\
\text { antimicrobial activity. New studies about antimicrobial effect of EOs in vivo conditions are } \\
\text { recommended. }\end{array}$
\end{tabular}

Keywords:

Staphyloccocus aureus, Antimicrobial activity Essential oils

Disc Diffusion Method Food

Türk Tarım - Gıda Bilim ve Teknoloji Dergisi, 8(4): 1012-1017, 2020

\section{Bitkilerden Elde Edilen Çeşitli Uçucu Yağların Gıda Kaynaklı Staphyloccus aureus Suşları Üzerindeki Antimikrobiyel Etkinliğinin Belirlenmesi}

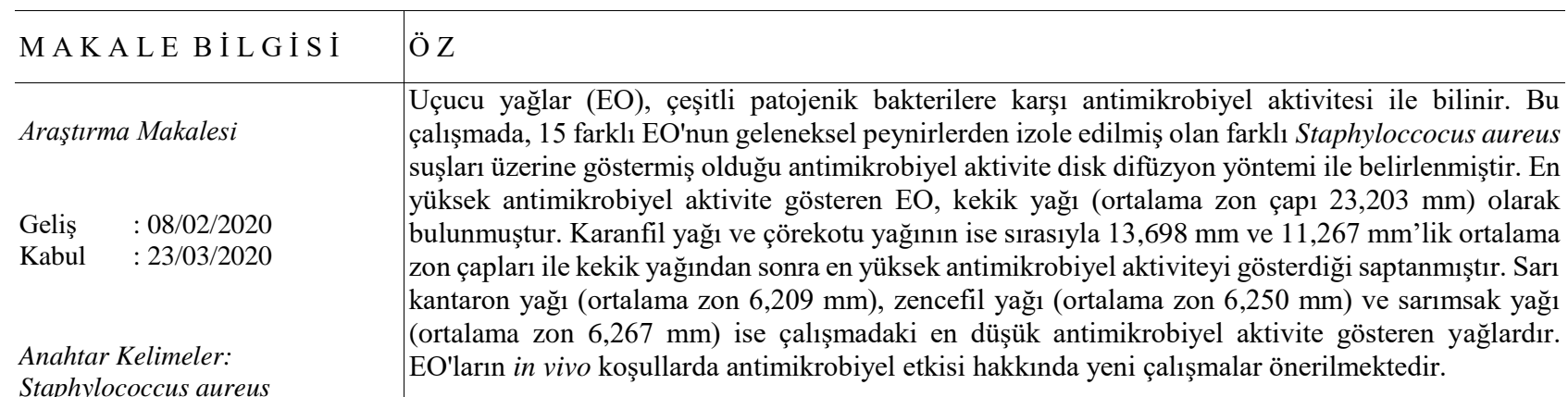

Antimikroccus aureus

Uçucu yağ

Disk difüzyon yöntemi

Gida 


\section{Introduction}

Essential oils (EOs) are volatile and fragrant compounds produced by plants with oily consistency (Bassole et al., 2012). EOs are mixtures of hydrocarbons and oxygenated hydrocarbons originating from the isoprenoid pathways, mainly composed of monoterpenes and sesquiterpenes (Sharifi-Rad et al., 2017). They are synthesized in plant organs such as flower, stem, fruit, seed and secreted by secretion cells, ducts, and glands (Cicioğlu-Arıdoğan et al., 2002; Bassole et al., 2012; Sharifi-Rad et al., 2017; de Aguiar et al., 2018).

Although the EOs obtained from different plants are in the chemical composition and the proportions of the substances in the composition obtained by different methods of extraction, their basic components belong to the same chemical classes as mono and sesquiterpene, aldehyde, ketone, ether and ester, alcohol and hydrocarbons (Sharifi-Rad et al., 2017). For example, thyme and carvarol are the predominant constituents in thyme oil. The dominant active ingredient of clove essential oil is eugenol; most active substances found in black seed oil are thymokinone and p-sinene (Bulca et al., 2014; Han et al., 2017; Omonjio et al., 2018). Eucalyptus oil, laurel oil and sage oil is the dominant active ingredient 1.8 cineol (dos Santos et al., 2007; Barbosa et al., 2016; Gölükçü et al., 2017). Similarly, rosemary essential oil contains 1.8 cineol and camphor; $\alpha$ pinene and limonene in cumin oil, $\alpha$ felladren and limonene in dill oil; $\alpha$ pinene and $\alpha$ felladren in ginger oil and limonene and $\alpha$ pinene in pine oil are predominantly active substances (Hussain et al., 2010; Radulescu et al., 2010; Sultan et al., 2005; Demirci et al., 2015).

Although their practical use dates back to hundreds of years, it has only recently been scientifically approved. EOs are often used in cosmetics, medicine and food industry. However, EOs are known to have antimicrobial, antifungal and insecticidal activities (Cicioğlu-Arıdoğan et al., 2002). Antimicrobial activity of EOs is depended on the source of plant, concentration of the target microorganism, the composition of the substrate, the production and storage conditions of the food (Faydaoğlu et al., 2013). The mechanism of action of EOs is realized by the ability of phenolic monoterpenes to alter microbial cell permeability, cytoplasmic damage, interfere with cellular energy system and disrupt proton motility. Cytoplasmic membrane damage leads to cell death. (Burt et al., 2004; Li et al., 2011; Calo et al., 2014). Some EOs have been reported to inhibit the growth of microorganisms in food sources and prolong the shelf life of processed foods (Cosentino et al., 1999; Barbosa et al., 2016; Mohammadpour et al., 2012). In recent years, EOs have attracted scientific interest because of their potential as a source of biologically active compounds with antimicrobial and antiviral activities that can replace traditional protectives, antibiotics and pesticides (CicioğluArıdoğan et al.,2002; Herman et al., 2015; de Aguiar et al., 2018).

Salmonella enterica, Staphylococcus aureus, Bacillus cereus, Clostridium perfringens, C. botulinum, Campylobacter jejuni, Escherichia coli O157: H7 and Listeria monocytogenes may cause foodborne outbreaks (Seow et al., 2013; de Aguiar et al., 2018). Although antibiotic use is required for the treatment of these bacteria, the development of antibiotic resistance is the most important factor in treatment failure (Seow et al., 2013; Sevindik et al., 2017). Concerns about consumers' negative perceptions of chemical preservatives have encouraged the food industry to look for new and reliable alternatives, and natural preservatives have begun to be developed (Güner et al., 2012; Seow et al., 2013; Mohammed et al., 2018; Pehlivan and Sevindik, 2018).

In this way, the objectives of this study were to evaluate the in vitro activity of 15 different EOs, by disc diffusion methods, against field isolates of $S$. aureus strains isolated from traditional cheeses in Ankara.

\section{Materials and Methods}

\section{Essential Oils}

In this study, 15 different commercial pure oils (purity $\geq 98 \%$ ) (Balen ${ }^{\mathrm{TM}}$, Ankara) were purchased from herbalists was tested. The purity and composition of which was determined by the manufacturer. These EOs were: Hypericum perforatum L, Ginger, Garlic, Laurel, Juniper, Cumin, Pine, Eucalyptus, Dill, Rosemary, Mint, Sage, Black seed, Clove and Thyme. All the oils were stored at room temperature in the dark prior to testing.

\section{Bacterial Isolates}

In this study, 85 different $S$. aureus strains isolated from traditional cheeses and the reference strain used in this study ( $S$. aureus ATCC6538) were obtained from the culture collection of Food Microbiology Laboratory, Department of Food Engineering, Ankara University, Ankara, Turkey. These strains inoculated on Tryptic Soy Broth (TSB) (Sigma ${ }^{\mathrm{TM}}$, Germany) and Brain Heart Infusion (BHI) broth (Merck ${ }^{\mathrm{TM}}$, Germany) and incubated at $35^{\circ} \mathrm{C}$ for $24 \mathrm{~h}$. All of the strains used in this study were stored at $-20^{\circ} \mathrm{C}$ with $30 \%(\mathrm{v} / \mathrm{v})$ glycerol $\left(\mathrm{Merck}^{\mathrm{TM}}\right.$, Germany).

\section{Preparation of Essential Oils for Testing}

A sterile $6 \mathrm{~mm}$ diameter white disk (Oxoid Ltd, ES) impregnated with $15 \mu \mathrm{L}$ of pure EO was prepared. The discs were soaked for a night.

\section{Disc Diffusion Method}

As a preliminary step, the antibacterial activity of the EOs was determined by the disk diffusion method. Briefly, steril $90 \mathrm{ml}$ TSA medium was prepared. Meanwhile, from an overnight culture, a suspension of $1 \times 10^{8} \mathrm{CFU} / \mathrm{mL}$ was prepared in sterile saline solution. Ten $\mathrm{mL}$ bacterial suspensions were transfered onto TSA medium, mixed with shaker and poured into sterile petri dishes. After ensuring that the media solidified, the discs impregnated with different oils numbered 1 to 15 were placed in the petri dishes and allowed to incubate at $37{ }^{\circ} \mathrm{C}$ for 24 hours. Furthermore, the effect of the volatile fraction of every EO was studied with the inverted Petri dish method (de Aguiar et al. 2017). The antibacterial activity was evaluated by measuring in millimeters the diameter of the inhibitory zone. All experiments were conducted in duplicate. 


\section{Statistical Analysis}

The results were evaluated by repeated measures ANOVA. The obtained measurements were tested by twoway ANOVA analysis. Post-Hoc (Tukey-HSD) tests were performed for factors that were found to be significant as a result of variance analysis.

\section{Results and Discussion}

In our study, the antimicrobial activity of commercially available pure EOs obtained from 15 different plants on $S$. aureus strains was investigated. Zone measurements were made by taking into account the completely transparent diameter around the disk. Zone formation around the disc is shown in Figure 1. The values comparing the mean measurements of the zone diameters for different types of EOs are shown in Table 1 and the graph of the same results is shown in Figure 2. EOs susceptibility of $S$. aureus strains is also showed in Table 2. Within the scope of the study, the diameters of 15 different EOs were investigated by means of a ruler and averages of parallels were obtained for 86 strains of $S$. aureus.

As a result of the study, significant differences were found in the $95 \%$ confidence interval between the activities of EOs. According to the results, the most effective antimicrobial EO was determined as thyme oil (average zone $23.203 \mathrm{~mm}$ ). The highest antimicrobial activity after thyme oil was found as clove (mean zone $13.698 \mathrm{~mm}$ ) and black seed oil (mean zone $11.267 \mathrm{~mm}$ ) respectively. $H$. perforatum oil (mean zone $6.209 \mathrm{~mm}$ ), ginger oil (mean zone $6.250 \mathrm{~mm}$ ) and garlic oil (mean zone $6.267 \mathrm{~mm}$ ) were the lowest antimicrobial activity in the study.

The highest antimicrobial activity was found in tyme oil with a zone diameter of $23.203 \mathrm{~mm}$. According to our results, all strains tested were sensitive to thyme oil. The antimicrobial activity of thyme oil was measured as zone diameter above $20 \mathrm{~mm}$ in $47(54.7 \%)$ of $86 \mathrm{~S}$. aureus strains and these strains were found to be very sensitive to thyme oil. $35(40.7 \%)$ of the strains were moderately sensitive and zone ranges were $15 \mathrm{~mm}-20 \mathrm{~mm} .4(4.7 \%)$ strains were found to be less sensitive to this oil ( $9 \mathrm{~mm}-14$ $\mathrm{mm}$ zone diameter). Thyme oil is an oil with high antimicrobial activity due to its predominant components, thymol and carvocrole (Bayaz et al., 2014). Carvacrol and thymol breakdown the bacterial cell membrane and causes the cell material to leave the cell (Chaieb et al., 2017). In our studies, the antimicrobial activity of thyme oil was similar to different studies (Çon et al., 1998; Ertürk et al., 2010; Radünz et al., 2019). We found that antimicrobial activity on thyme against $S$. aureus was determined as a zone diameter of $29 \mathrm{~mm}$. In previously both studies (Çon et al., 1998; Ertürk et al., 2010), thyme oil showed activity above $20 \mathrm{~mm}$ zone diameter. In this context, the results of this study were consistent with them. Lambert et al. (2001) studied the antimicrobial activity of thymol and carvocrol on $S$. aureus and $P$. aureginosa, and found that the combined use of thymol and carvocrol showed higher antimicrobial activity than when used alone. These results suggest that thyme oil may be the cause of the higher inhibitory effect than a volatile oil containing only one of thymol or carvocrole.

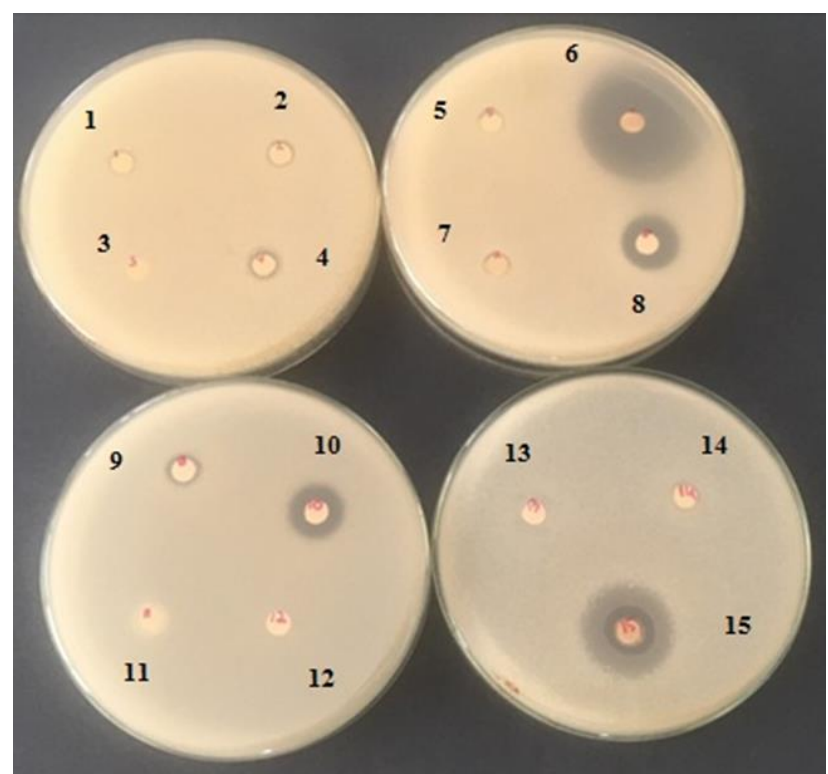

Figure 1. Inhibition zones formed by volatile oils around the disc (Staphylococcus aureus ATCC6538)

(Disc 1: eucalyptus oil, disc 2: dill oil, disc 3: juniper oil, disc 4: rosemary oil, disc 5: ginger oil, disc 6: thyme oil,disc 7: Hypericum perforatum oil, disc 8: mint oil, disc 9: sage oil, disc 10: clove oil, disc 11: garlic oil, disc 12: pine oil, disc 13: Laurel oil, disc 14: cumin oil, disc 15: black seed oil)

Table 1. Average zone diameters and standard deviation values of Eos*

\begin{tabular}{l|cc}
\hline \multicolumn{1}{c|}{ Essential oils } & Mean & Standard Deviation \\
\hline Hypericum perforatum & $6.21^{\mathrm{a}}$ & 0.65 \\
Ginger & $6.25^{\mathrm{a}}$ & 0.78 \\
Garlic & $6.27^{\mathrm{a}}$ & 0.72 \\
Laurel & $6.33^{\mathrm{a}, \mathrm{b}}$ & 0.95 \\
Juniper & $6.49^{\mathrm{a}}, \mathrm{b}$ & 1.31 \\
Cumin & $6.51^{\mathrm{b}}, \mathrm{c}$ & 1.35 \\
Pine & $6.85^{\mathrm{c}},{ }^{\mathrm{d}}$ & 1.72 \\
Eucalyptus & $7.08^{\mathrm{d}}$ & 1.41 \\
Dill & $7.52^{\mathrm{e}}$ & 2.12 \\
Rosemary & $8.47^{\mathrm{f}}$ & 2.15 \\
Mint & $8.63^{\mathrm{f}}$ & 3.23 \\
Sage & $9.44^{\mathrm{g}}$ & 1.61 \\
Black seed & $11.27^{\mathrm{h}}$ & 5.57 \\
Clove & $13.7^{\mathrm{i}}$ & 6.82 \\
Thyme & $23.2^{\mathrm{j}}$ & 8.67 \\
\hline \multicolumn{2}{l}{} \\
\hline
\end{tabular}

*The difference between the mean values of oil types was statistically significant ( $F=164,709 ; \mathrm{P}<0.001)$. The smallest significant difference test (LSD: Least Significant Difference) was performed for multiple comparisons to determine the source of the differences. In case of no significant difference between the groups, the mean values were indexed with the same letter.

In our study, clove oil was found to be the most effective oil after thyme oil. The average zone diameter of clove oil was $13.698 \mathrm{~mm}$. While a total of 85 strains were sensitive to clove oil, only one strain had no antimicrobial activity. In this study, $8(9.3 \%)$ strains were very sensitive to clove oil and $20(23.3 \%)$ strains were found to be moderately sensitive 57 (63.3\%) strains. 


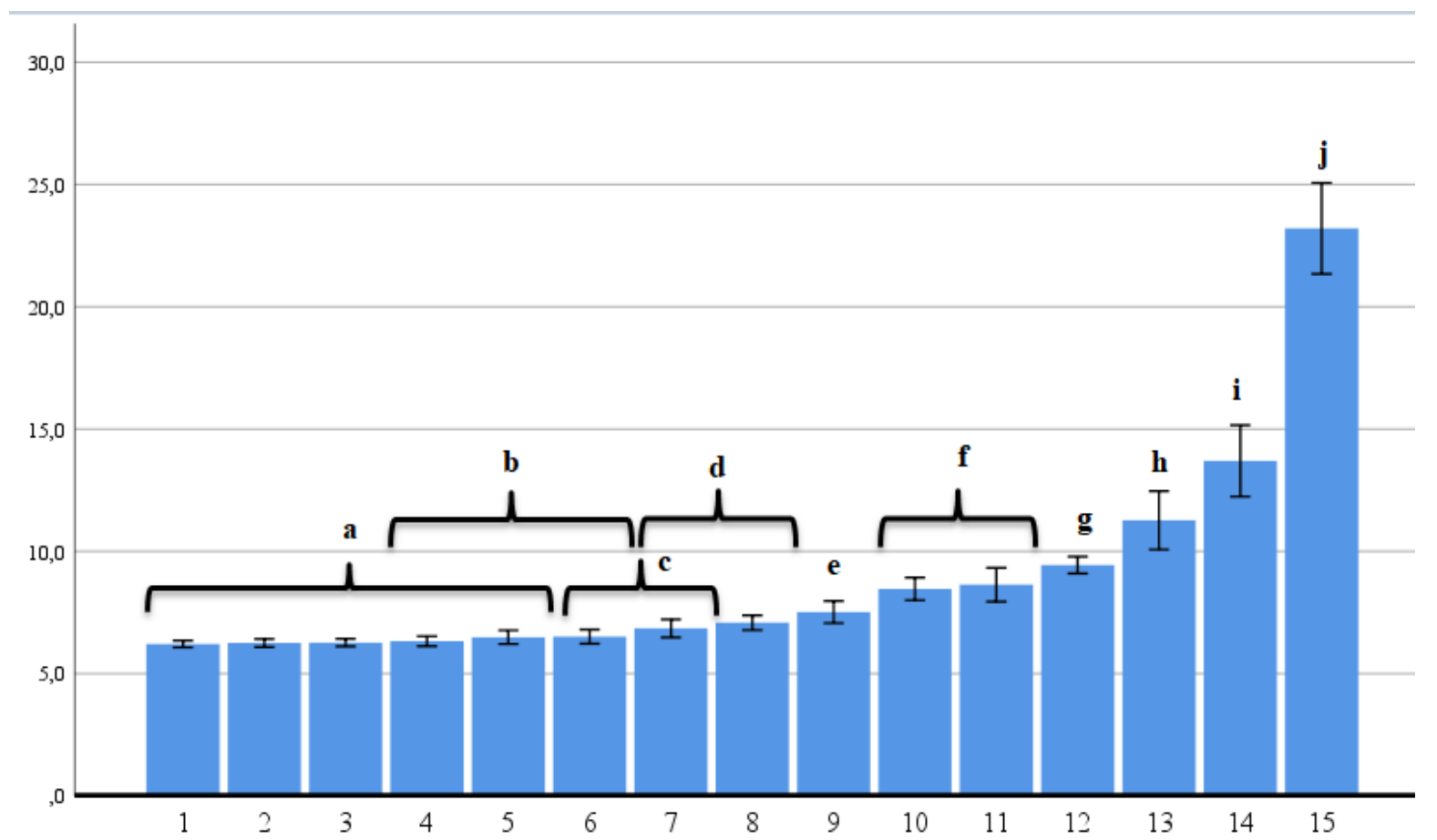

Figure 2. Comparison of measurement diameters of zone diameters for different types of Eos

Table 2. EOs susceptibility of Staphylococcus aureus strains

\begin{tabular}{l|cccccccc}
\hline \multirow{2}{*}{ Essential Oils } & \multicolumn{3}{|c}{$-^{\mathrm{a}}$} & \multicolumn{3}{c}{$+^{\mathrm{b}}$} & \multicolumn{3}{c}{$++^{\mathrm{c}}$} & \multicolumn{3}{c}{$+{ }^{\mathrm{d}}$} \\
\cline { 2 - 9 } & $\mathrm{n}$ & $\%$ & $\mathrm{n}$ & $\%$ & $\mathrm{n}$ & $\%$ & $\mathrm{n}$ & $\%$ \\
\hline Hypericum perforatum & 82 & 95.3 & 4 & 4.7 & 0 & 0.0 & 0 & 0.0 \\
Ginger & 81 & 94.2 & 5 & 5.8 & 0 & 0.0 & 0 & 0.0 \\
Garlic & 84 & 97.7 & 2 & 2.3 & 0 & 0.0 & 0 & 0.0 \\
Laurel & 80 & 93.0 & 6 & 7.0 & 0 & 0.0 & 0 & 0.0 \\
Juniper & 78 & 90.7 & 7 & 8.1 & 1 & 1.2 & 0 & 0.0 \\
Cumin & 77 & 89.5 & 9 & 10.5 & 0 & 0.0 & 0 & 0.0 \\
Pine & 72 & 83.7 & 14 & 16.3 & 0 & 0.0 & 0 & 0.0 \\
Eucalyptus & 66 & 76.7 & 20 & 23.3 & 0 & 0.0 & 0 & 0.0 \\
Dill & 58 & 67.4 & 28 & 32.6 & 0 & 0.0 & 0 & 0.0 \\
Rosemary & 39 & 45.3 & 46 & 53.5 & 1 & 1.2 & 0 & 0.0 \\
Mint & 46 & 53.5 & 33 & 38.4 & 7 & 8.1 & 0 & 0.0 \\
Sage & 12 & 14.0 & 73 & 84.9 & 1 & 1.2 & 0 & 0.0 \\
Black seed & 37 & 43.0 & 22 & 25.6 & 19 & 22.1 & 8 & 9.3 \\
Clove & 1 & 1.2 & 57 & 66.3 & 20 & 23.3 & 8 & 9.3 \\
Thyme & 0 & 0.0 & 4 & 4.7 & 35 & 40.7 & 47 & 54.7 \\
\hline
\end{tabular}

a: $\leq 8 \mathrm{~mm}$; b: between $8 \mathrm{~mm}$ and $14 \mathrm{~mm}$; c: between $14 \mathrm{~mm}$ and $20 \mathrm{~mm}$; $\mathrm{d}:>20 \mathrm{~mm}$

Moreira et al. (2005) in their study of eucalyptus, tea tree, rosemary, mint, rose, clove, lemon, thyme, pine and basil plants obtained from the essential oils of different E.coli O157: H17 strains tested on the antimicrobial activity. They found that clove oil was the highest activity oil. Metin et al. (2016) investigated the antimicrobial activity of $100 \%$ pure commercial oils of clove, mint and lavender plants against some bacterial fish pathogens. As a result of their study, it was found that clove oil was the highest antimicrobial activity and certain concentrations of the other two oils showed inhibition properties. Antimicrobial activity in cloves has been reported to be due to eugenol in oil structure (Chaieb et al., 2017; YücelŞengün et al., 2018). Quattara et al. (1997) found that the most effective essential oils belong to cloves, cinnamon, allspice and rosemary cinnamon, cloves, allspice, rosemary, black pepper, marjoram, garlic and cumin essential oils of different dilutions were identified against 2 Gram negative and 4 Gram positive bacteria. They stated that the common feature of these oils was eugenol and cinnamaldehyde. Radünz et al. (2019) investigated the antimicrobial efficacy of clove oil on S. aureus, E. coli, $L$. monocytogenes and $S$. typimurium and determined the antimicrobial activity as $28.3 \mathrm{~mm}, 28.1 \mathrm{~mm}, 24.7 \mathrm{~mm}$ and $22.2 \mathrm{~mm}$, respectively. It was thought that the zone value found for S.aureus is considerably higher than the average zone value found in our study. Around the disc, two different zones can be formed: a fully transparent zone and a fuzzy transparent zone. In the evaluation section, only the evaluation of the transparent zone and the evaluation of the total zone formation cannot make the results mathematically different (Radünz et al., 2019). 
In our study, the highest activity after black seed oil, oregano and clove oil was determined as the third oil. The average zone value of black seed oil was found to be $11.267 \mathrm{~mm}$. A total of 49 strains were found to be sensitive to black seed oil. In $8(9.3 \%)$ of these strains, values above $20 \mathrm{~mm}$ zone diameter were determined and these strains were determined as very sensitive. Nineteen $(22.1 \%)$ of them were found to be moderately sensitive to black seed oil and $22(25.6 \%)$ were less sensetive. The antimicrobial activity of black seed oil is supported by different studies. Nair et al. (2005), the seed oil of black seed plant on $L$. monocytogenes investigated the antimicrobial activity. In this study, a disc containing impregnated black seed oil and sunflower oil and a disc containing gentamicin were used. They found that the highest antimicrobial activity was shown by black seed oil with an average zone value of 31.5 $\mathrm{mm}$ (Nair et al., 2005). It is thought that the difference between the zone value in the study of Nair et al. (2005) and the zone value in our study stems from the difference in microorganism tested. Antimicrobial efficacy of black seed oil has been reported in different studies similar to our study. Thymokinone, the dominant substance found in black seed oil, has been shown to exhibit antimicrobial activity against bacterial strains such as E. coli, S. aureus, $P$. aureginosa and $B$. subtilis and especially bactericidal activity against gram positive cocci (Khan et al., 2003; Chaieb et al., 2011; Güzelsoy et al., 2018).

Antimicrobial activity of sage, mint and rosemary oils on $S$. aureus strains was also determined in our study. The mean antimicrobial activity of sage oil on $S$. aureus was $9.44 \mathrm{~mm}$, while the mean peppermint oil was $8.63 \mathrm{~mm}$ and the mean antimicrobial activity of rosemary oil was also $8.47 \mathrm{~mm}$. While 12 (14\%) strains, $46(53.5 \%)$ strains and $39(45.3 \%)$ strains were insensitive to these fats, 73 $(84.9 \%)$ strains, $33(38.4 \%)$ strains and $46(53.5 \%)$ strains were less sensitive, respectively. Among them, 1 (1.2\%) strains, $7(8.1 \%)$ strains and $1(1.2 \%)$ strains were identified as medium susceptible. None of the strains were found in the very sensitive category for all three fats. The results obtained from the study were consistent with the results of different researchers. Moreira et al. (2005), Metin et al. (2016) and Quattara et al. (1997)'s results were in parallel with our results.

In our study, mean zone values of dill, pine, cumin and ginger oils were determined as $7.52 \mathrm{~mm}, 6.85 \mathrm{~mm}, 6.51$ $\mathrm{mm}$ and $6.25 \mathrm{~mm}$ respectively. While $58(67.4 \%)$ of the strains were found insensitive to dill oil, 28 (32.6\%) were found to be less sensitive. While pine oil was not effective in $72(83.7 \%)$ strains, $9 \mathrm{~mm}-14 \mathrm{~mm}$ zone diameter was determined on $14(16.3 \%)$ strains. Similarly, while 77 $(89.5 \%)$ strains were insensitive to cumin oil, the remaining $9(10.5 \%)$ strains were found to be less sensitive (9 mm-14 mm zone diameter). While 81 strains $(94.2 \%)$ were insensitive to ginger oil, only 5 strains $(5.8 \%)$ were less sensitive $(9 \mathrm{~mm}-14 \mathrm{~mm})$. According to our results, ginger oil was determined as the lowest antimicrobial activity oil after $H$. perforatum oil. Cumin, dill, ginger and pine oils contain at least one common substance. $\alpha$ - pinene and limonene in cumin oil, $\alpha$-felladren and limonene in dill oil; $\alpha$-pinene and $\alpha$-felladren in ginger oil and limonene and $\alpha$ - pinene in pine oil are the predominant active ingredients (Sultan et al., 2005; Hussain et al., 2010; Radulescu et al., 2010; Mohammadpour et al., 2012; 1016
Demirci et al., 2015). Low levels of antimicrobial activity suggest that $\alpha$-pinene and limonene and felladren alone or in combination have no effect on $S$. aureus strains.

In our study, the lowest antimicrobial activity oils were H.perforatum (average zone diameter: $6.21 \mathrm{~mm}$ ), ginger (average zone diameter: $6.25 \mathrm{~mm}$ ), garlic (average zone diameter: $6.27 \mathrm{~mm}$ ), laurel (average zone diameter 6.33 $\mathrm{mm}$ ), juniper (average zone diameter $6.49 \mathrm{~mm}$ ) and cumin (6.51 mm). On a total of $86 \mathrm{~S}$. aureus strains, $82(95.3 \%)$, $81(94.2 \%), 84(97.7 \%), 80(93.0 \%), 78(90.7 \%)$ and 77 $(89.5 \%)$ strains were found insensitive to these five fats. None of the strains had a zone diameter greater than 20 $\mathrm{mm}$. Except for juniper oil (1 strain), no strain was found to be moderately sensitive to these oils. 4 strains $(4.7 \%)$ were used for $H$. perforatum oil, 5 strains $(5.8 \%)$ for ginger oil, 2 strains (2.3\%) for garlic oil, 6 strains $(7.0 \%)$ for laurel oil, 7 strains $(8.1 \%)$ for juniper oil and 9 strains $(10.5 \%)$ was found to be less sensitive to cumin oil. Our study results differ from other studies. In our study, antimicrobial activity of garlic and cumin oil on $S$. aureus was determined. Quattara et al. (1997) found that antimicrobial activity of garlic and cumin oil. The difference between the two studies is thought to be due to the difference in the bacterial strain tested. Biondi et al. (1993) on the other hand, the dilution of $1 / 2$ of the laurel oil in $1 / 2,1 / 5$ and $1 / 10$ dilutions of laurel oil has an antimicrobial effect on $S$. aureus and they do not observe any efficacy in other dilutions. In our study, pure laurel oil had very limited antimicrobial activity on S.aureus. In this context, between our results and Biondi et al. (1993)'s result were not compatible. It is thought that this difference may be caused by different varieties and virulence characteristics of the strains even if they are the same species.

\section{Conclusion}

Aromatic plants and the essential oils obtained from these plants have been used for various purposes such as the treatment of diseases among the people and preservatives and flavors in the food for centuries. The use of synthetic additives and antimicrobials that have increased with the advancing technology have had many side effects on health and the need to investigate new sources such as the resistance of microorganisms to synthetic antimicrobials. As a result, the use of medicinal and aromatic plants and the essential oils obtained from them has come to the fore again and efforts to improve the use of these products in medicine, cosmetics, agriculture and food have accelerated. The results of the studies on the antibacterial, antifungal, antiviral, insecticide and food protective effects of the essential oils obtained from plants are generally positive. Therefore, an alternative way of using herbal essential oils is thought.

\section{References}

Barbosa LCA, Filomeno CA, Teixeira RR. 2016. Chemical variability and biological activities of Eucalyptus spp. essential oils. Molecules. doi:10.3390/molecules21121671.

Bassolé IHN, Juliani HR. 2012. Essential oils in combination and their antimicrobial Properties. Molecules. 17: 3989-4006; doi:10.3390/molecules17043989.

Bayaz M. 2014. Esansiyel Yağlar: Antimikrobiyal, antioksidan ve antimutajenik aktiviteleri. Akademik Gıda. 12(3): 45-53. 
Biondi D, Cianci P, Gerad C, Giuseppe R. 1993. Antimicrobial activity and chemical composition of essential oils from sicilian aromatic plants. Flavour and Fragrance Journal, 8: 331-337.

Bulca S. 2014. Çörek otunun bileşenleri ve bu yağın ve diğer bazı uçucu yağların antioksidan olarak gıda teknolojisinde kullanımı. Journal of Adnan Menderes University Agricultural Faculty. 11(2): $29-36$.

Burt S. 2004. Essential oils: their antibacterial properties and potential applications in foods - a review. International Journal of Food Microbiology. 94: 223- 253.

Calo JR, Crandall PG, O’Bryan CA, Ricke SC. 2014. Essential oils as antimicrobials in food systems- a review. Food Control.doi:10.1016/jfoodcont2014.12.040.

Chaieb K, Kouidh B, Jrah H, Mahdouani K, Bakhrouf A. 2011. Antibacterial activity of thymoquinone, an active principle of Nigella sativa and its potency to prevent bacterial biofilm formation. BMC Complementary and Alternative Medicine. 11:29.

Chaieb K, Hajlaou H, Zmantar, T, Kahla-Nakb AB, Rouabhia, M, Mahdouani K, Bakhrouf A. 2007. The chemical composition and biological activity of clove essential oil, Eugenia caryophyllata (Syzigium aromaticum L. myrtaceae): a short review. Phytotherapy Research.21: 501-506.

Cicioğlu Arıdoğan B, Baydaf H., Kay S, Demirci, M, Ozbaşar D, Mumcu E. 2002. Antimicrobial activity and chemical composition of some essential oils. Archives of Pharmacal Research. 25(6): 860-864.

Cosentino, S, Tuberoso CIG, Pisano B, Satta M, Mascia V, Arzedi E, Palmas F. 1999. In-vitro antimicrobial activity and chemical composition of Sardinian Thymus essential oils. Letters in Applied Microbiology. 29; 130-135.

Çon AH, Ayar A, Gökalp HY. 1998. Bazı baharat uçucu yağlarının bakterilere karşı antimikrobiyal etkisi. Gıda. 23(3): 171-175.

de Aguiar FC, Solarte AL, Tarradas C, Luque I, Maldonado A, Galán-Relaño A, Huerta B. 2018. Antimicrobial activity of selected essential oils against Streptococcus suis isolated from pigs. Microbiology Open. doi: 10.1002/mbo3.613.

Demirci F, Bayramiç P, Göger G, Demirci B, Can Başer KHC. 2015. Characterization and antimicrobial evaluation of the essential oil of Pinus pinea L. from Turkey. Natural Volatiles and Essential Oils. 2(2): 39-44.

dos Santos ACA, Lerin LA, de Luccio M, Mossi A., Atti- Sefarini L, Cansiani, RL, Oliveria, JV. 2007. Chemical characterization and antimicrobial activity of essential oils of Salvia L. species. Ciência e Tecnologia de Alimentos. 29(4): 764-770.

Ertürk R, Çelik C, Kaygusuz R, Aydın H. 2010. Ticari olarak satılan kekik ve nane uçucu yağlarının antimikrobiyal aktiviteleri. Cumhuriyet T1p Dergisi. 32: 281-286.

Faydaoğlu E, Sürücüoğlu MS. 2013. Tıbbi ve aromatik bitkilerin antimikrobiyal, antioksidan aktiviteleri ve kullanım olanakları. Fen Bilimleri Enstitüsü Dergisi, 6(2): 233-265.

Gölükçü M, Tokgöz H, Turgut DY. 2017. Defne (Laurus nobilis) uçucu yağ bileşimi üzerine distilasyon süresinin etkisi. Food and Health, 4(1); 37-42.

Güner A, Atasever M, Aydemir- Atasever M. 2012. Yeni ortaya çıkan ve tekrar önem kazanan gida kaynaklı bakteriyel patojenler. Kafkas Universitesi Veteriner Fakultesi Dergisi. 18(5): 889-898.

Güzelsoy P, Aydın S, Başaran N. 2018. Çörek otunun (Nigella sativa $\mathrm{L}$.) aktif bileşeni timokinonun insan sağllğ 1 üzerine olas1 etkileri. Journal of Literature Pharmacy Sciences. 7(2):118-35.

Han X, Parker TL. 2017.Anti-inflammatory activity of clove (Eugenia caryophyllata) essential oil in human dermal fibroblasts. Pharmaceutical Biology.55(1): 1619-1622.

Herman A, Tambo K, Herman A. 2015. Linalool affects the antimicrobial efficacy of essential oils. Current Microbiology. doi: 10.1007/s00284-015-0933-4.
Hussain AI, Anwar F, Chatha SAS, Jabbar A, Mahboob S, Nigam PS. 2010. Rosmarinus officinal is essential oil: antiproliferative, antioxidant and antibacterial activities. Brazilian Journal of Microbiology.41: 1070-1078.

Khan MAU, Ashfaq MK, Zuberi HS, Mahmood MS, Gilani AH. 2003. The in vivo antifungal activity of the aqueous extract from Nigella sativa seeds. Phytotherapy Research.17: 183186.

Lambert RJW, Skandamis PN, Coote PJ, Nychas GJE. 2001. A study of the minimum inhibitory concentration and mode of action of oregano essential oil, thymol and carvacrol. Journal of Applied Microbiology. 91: 453-462.

Li M, Muthaiyan A, O’Bryan C, Gustafson JE., Li Y. 2011. Use of natural antimicrobials from a food safety perspective for control of Staphylococcus aureus. Current Pharmaceutical Biotechnology. 12: 1240-1254.

Metin S, Didinen BI, Mercimek EB, Ersoy AT. 2017. Bazı bakteriyel balık patojenlerine karşı bazı bitkisel uçucu yağlarının antibakteriyel aktivitesi. Araştırma Bülteni. 1: 59-69.

Mohammed FS, Akgul H, Sevindik M, Khaled BMT. 2018. Phenolic content and biological activities of Rhus coriaria var. zebaria. Fresenius Environmental Bulletin. 27(8): 56945702.

Mohammadpour H, Moghimipour E, Rasooli I, Fakoor MH, Astaneh, SA, Moosaie SS, Jalili Z. 2012. Chemical composition and antifungal activity of Cuminum cyminum $\mathrm{L}$. essential oil from alborz mountain against Aspergillus species. Jundishapur Journal of Natural Pharmaceutical Products. 7(2):50-55.

Moreira MR, Ponce AG, del Valle CE, Roura SI. 2005. Inhibitory parameters of essential oils to reduce a foodborne pathogen. Lebensmittel-Wissenschaft \& Technologie. 38: 565-570.

Nai MKM, Vasudevan, P, Venkitanarayanan K. 2005. Antibacterial effect of black seed oil on Listeria monocytogenes. Food Control.16:395-398.

Omonjio FA, Ni L, Gong J, Wang Q, Lahaye L, Yang C. 2018. Essential oils as alternatives to antibiotics in swine production. Animal Nutrition. 4: 126-136.

Quattara B, Simard RE, Holley RA, Piette GJP, Begin A. 1997. Antibacterial activity of selected fatty acids and essential oils against six meat spoilage organisms. International Journal of Food Microbiology. 37: 155-162.

Pehlivan M, Sevindik M. 2018. Antioxidant and antimicrobial activities of Salvia multicaulis. Turkish Journal of Agriculture-Food Science and Technology. 6(5): 628-631.

Radulescu V, Popescu ML, Ilies DC. 2010. Chemical composition of the volatile oil from different plant parts of Anethum graveolens L. (Umbelliferae) cultivated in Romania. Farmacia. 58(5).

Radünz M, Trindade MLM, Camargo TM, Radünz AL, Borges CD, Gandra EA, Helbig E. 2019. Antimicrobial and antioxidant activity of unencapsulated and encapsulated clove (Syzgium aromaticum L.) oil. Food Chemistry.276: 180-186.

Seow YX, Yeo CR, Chung H, Yuk HG. 2013. Plant essential oils as active antimicrobial agents. Critical Reviews in Food Science and Nutrition. 54:625-644.

Sevindik M, Akgul H, Pehlivan M, Selamoglu Z. 2017. Determination of therapeutic potential of Mentha longifolia ssp. longifolia. Fresen Environ Bull. 26(7): 4757-4763.

Sharifi-Rad J,Sureda A, Tenore GC, Daglia M, Sharifi-Rad M, Valussi M, Tundis R, Sharifi-Rad M, Loizzo MR, Ademiluyi AO, Sharifi-Rad R, Ayatollahi SA, Iriti M. 2017. Biological activities of essential oils: from plant chemoecology to traditional healing systems. Molecules. 22(70).

Sultan M, Bhatti HN, Iqbal Z. 2005. Chemical analyses of essential oil of ginger (Zingiber officinale). Pakistan Journal of Biological Sciences.8(11): 1576-1578.

Yücel Şengün İ, Öztürk B. 2018. Bitkisel kaynaklı bazı doğal antimikrobiyaller. Anadolu University Journal of Science and Technology C- Life Sciences and Biotechnology.7(2): 256-276 